\title{
Activation of an intron enhancer within the keratin 18 gene by expression of $c$-fos and c-jun in undifferentiated F9 embryonal carcinoma cells
}

\author{
Robert G. Oshima, ${ }^{1}$ Leslie Abrams, and David Kulesh \\ Cancer Research Center, La Jolla Cancer Research Foundation, La Jolla, California 92037 USA
}

\begin{abstract}
The mouse forms of human keratins 18 and 8 (K18 and K8) are the first members of the large intermediate filament gene family to be expressed during embryogenesis. To identify potential regulatory elements of the human K18 gene, various recombinant constructions were expressed in cultured cells. An enhancer element was found in the first intron that functions on both the K18 and thymidine kinase promoters in differentiated cells. In F9 embryonal carcinoma cells, the level of expression was low in the presence or absence of the first intron. Cotransfection of $F 9$ cells with $\mathrm{K} 18$ constructs that include the first intron and increasing amounts of an expression vector of c-jun results in a modest increase in the reporter gene expression. Cotransfection of the same construct with increasing amount of the mouse c-fos gene results in activation of the reporter gene by as much as 15-fold, with a near linear response to the amount of $c$-fos gene added. Site-specific mutagenesis of a putative AP-1 site within the intron abolishes trans-activation by c-fos in F9 cells. Furthermore, induction of c-fos in a derivative of $F 9$ cells results in increased expression of the endogenous mouse form of K18. Cotransfection with c-jun or c-fos expression vectors had little effect on the expression of the K18 reporter construct in a parietal endodermal cell line already expressing the endogenous mouse gene. These results identify an enhancer within the first intron of $\mathrm{K} 18$ that may interact directly with c-jun and c-fos via a conserved AP-1-binding site. K18 expression in undifferentiated F9 cells may be limited by the low levels of $\mathrm{c}$ jun and c-fos.
\end{abstract}

[Key Words: K18; Endo B; keratin; embryonal carcinoma; c-jun; c-fos; enhancer]

Received August 28, 1989; revised version accepted February 12, 1990.

The differential expression of the mammalian genome begins within the first several cell divisions and results in the formation of the first phenotypically distinguishable differentiated cell type, the trophectoderm of the blastocyst embryo. Among the earliest differentially expressed genes are members of the intermediate filament (IF) gene family, the keratins (Steinert and Parry 1985). Endo B, the mouse form of human keratin $18(\mathrm{~K} 18)$, is a type I keratin protein that is first expressed just prior to blastocyst formation along with its normally coexpressed and complementary type II keratin partner, Endo A (Brûlet et al. 1980; Oshima et al. 1983; Duprey et al. 1985|. Expression of both proteins is restricted at the blastocyst stage to the trophectoderm and extraembryonic endoderm (Brûlet et al. 1980; Jackson et al. 1980; Chisholm and Houliston 1987). In adult tissues, $\mathrm{K} 18$ and keratin $8(\mathrm{~K} 8)$, the human form of Endo A, are coexpressed primarily in a variety of simple epithelial tissues (Moll et al. 1982). Sequence analysis indicates that $\mathrm{K} 18$ and $\mathrm{K} 8$ represent the first keratins from which

${ }^{1}$ Corresponding author. more specialized keratins were derived (Blumenberg 1988).

The differentiation of cultured murine embryonal carcinoma (EC) cells has been used as a convenient model system of early mouse development. (Hogan et al. 1983; Silver et al. 1983). Whereas undifferentiated murine EC cells do not express mouse $\mathrm{K} 18$ or K8, spontaneous or retinoic-acid-induced differentiation results in increased transcription of the respective genes (Oshima et al. 1988), appearance of the mRNAs and proteins, and their assembly into immunologically detectable IFs (Oshima 1981, 1982; Tabor and Oshima 1982; Duprey et al. 1985). Although neither EC cells nor most differentiated, nonepithelial cells such as fibroblasts express K18, the reasons that the two cell types do not express endogenous $\mathrm{K} 18$ appear to differ. The coding $\mathrm{K} 18$ gene in mouse fibroblasts (Endo B $\beta-1$ ) is hypermethylated and found in a DNase-resistant chromatin state. This apparently renders the gene unavailable for transcription because the Endo B $\beta-1$ gene remains silent even when placed in a permissive environment by somatic cell hybridization (Oshima et al. 1988). Exogenously intro- 
duced $\mathrm{K} 18$ is expressed efficiently in fibroblasts that do not express the endogenous gene (Kulesh and Oshima 1988). In contrast, the Endo B $\beta-1$ gene in F9 cells is not heavily methylated nor is it in a DNase-resistant chromatin state. Furthermore, F9 cells do not support the efficient expression of a transfected K18 gene (Kulesh and Oshima 1988; this work). Thus, it appears that expression of mouse $\mathrm{K} 18$ is restricted in nonepithelial differentiated cells by the accessibility of the gene to the transcriptional machinery. However, the restriction in F9 EC cells may be due to either the absence of necessary transcription factors or the presence of negative regulatory activities. In this study we show that the first intron of $\mathrm{K} 18$ has a tissue nonspecific enhancer activity. Furthermore, the enhancer activity can be activated in F9 cells by the expression of either c-iun or c-fos, suggesting that $\mathrm{K} 18$ expression in $\mathrm{F} 9$ cells may be limited, at least in part, by the low levels of these proto-oncogene transcription factors.

\section{Results \\ Deletion analysis of K18 regulatory elements}

In previous studies we showed that the $\mathrm{K} 18$ gene was expressed efficiently in mouse cell lines after DNA transfection of the whole gene (Kulesh and Oshima 1988). To begin to assess the degree to which the regulatory sequences of the $\mathrm{K} 18$ gene direct appropriate tissuespecific expression, a recombinant molecule termed K18POLac was constructed that substituted the bacterial LacZ gene (which codes for $\beta$-galactosidase) for the region of K18 from the beginning of exon 2 to near the end of the last exon (exon 7) (Fig. 1, construct 4). To identify regions of the $\mathrm{K} 18$ gene necessary for expression, K18P0Lac and the related recombinant constructs shown in Figure 1 were tested by transient transfection experiments in cultured cell lines. The results of transfecting these derivatives into Ltk- cells, which had been shown previously to express the whole K18 gene efficiently, are shown in Figure 2A.

Deletion of $1.45 \mathrm{~kb}$ of the $5^{\prime}$-flanking sequences of K18P0Lac (Fig. 1, construct 2) had relatively little effect on the expression of $\beta$-galactosidase activity (Fig. 2A, construct 2) relative to the parental vector (Fig. $2 \mathrm{~A}$, construct 4). This deletion removes two sequence elements that are highly conserved in the distal portion of the 5'flanking sequences of the $\mathrm{K} 18$ and Endo $\mathrm{B} \beta-1$ genes (Fig. $3 \mathrm{~A})$. Deletion of $2.2 \mathrm{~kb}$ of the $5^{\prime}$-flanking region of the K18 gene results in a plasmid that retained only $250 \mathrm{bp}$ of $5^{\prime}$-flanking sequence of the K18 gene (Fig. 1, construct 1). This plasmid had significant, but modestly decreased, activity when compared to the starting KPOLac construct (Fig. 2A, constructs 1 and 4). Removal of $3.4 \mathrm{~kb}$ of 3 '-flanking sequences (Fig. 1, construct 3 ) resulted in an increase in $\beta$-galactosidase expression relative to the activity of K18POLac (Fig. 2A, construct 3). The increased activity of K18P0Lac-Bam could possibly result from the removal of a site of interaction with a negative regulatory factor. However, competition experiments in- volving the cotransfection of $\mathrm{K} 18 \mathrm{POLac}$ with increasing amounts of a recombinant containing only the $3.4 \mathrm{~kb}$ of 3 '-flanking sequences failed to provide evidence for such factors (data not shown).

In contrast to the deletions of $5^{\prime}$-flanking sequences, removal of the first exon and first intron from the K18P0Lac vector (Fig. 1, construct 5) resulted in much lower expression of $\beta$-galactosidase (Fig. $2 \mathrm{~A}$, construct 5 ). This lower activity was not abrogated by the substitution of the SV40 $t$-antigen intron and polyadenylation signals for the $3^{\prime}$ end of the K18 gene (Figs. 1 and 2B, construct 6). Thus, the lower activity of K18P1LacL is not due simply to the absence of an intron. When tested in HR9 parietal endodermal cells, the relative activity of each of the constructs was very similar to those shown for $\mathrm{L}$ cells (Fig. 2B and data not shown).

To compare the relative activities of a subset of the constructs shown in Figure 1 in different cell types, plasmids were again cotransfected with the $\beta$-actin chloramphenicol acetyltransferase (CAT) vector. The results of a typical set of experiments are shown in Figure 2B. In all cells tested, the two constructs that lack the first exon and first intron of $\mathrm{K} 18$ (Figs. 1 and 2, constructs 5 and 6) were least active. HR9 parietal endodermal cells repeatedly expressed the K18POLac-Bam (Fig. 2B, construct 3) and the K18POLac vectors (Fig. 2B, construct 4) best, but Ltk ${ }^{-}$cells also were capable of expressing these vectors well. These results are consistent with our previous analysis of stable cell lines that express the K18 gene (Kulesh and Oshima 1988) and indicate that Ltk- cells, which do not express the endogenous, homologous mouse gene, are capable of expressing $\mathrm{K} 18$ or $\mathrm{K} 18$ constructs after direct transfection. NT2 human EC (Andrews et al. 1984) cells differ from mouse EC cells in several respects, including the constitutive expression of K18. NT2 cells were more capable of expressing the most active $\mathrm{K} 18$ constructs than F9 cells were but were still only modestly active in comparison to the two differentiated cell types, HR9 and Ltk- cells.

To confirm that $\beta$-galactosidase mRNA resulted from properly initiated, K18-directed transcription, RNA protection experiments were performed. Figure 4 shows the results of mapping the initiation site of RNA resulting from the transient transfection of HR9 cells with the KPOLac-Bam vector (Fig. 1, construct 3; Fig. 4, lane 6). The same size 240-nucleotide fragment of the probe was protected by RNAs derived from both NT2 cells that constitutively express K18 RNA (Fig. 4, lane 5) and HR9 cells transiently transfected with KPOLac-Bam (Fig. 4, bottom).

\section{Transcriptional enhancement by the first intron of K18}

Comparison of the sequences of the K18 gene (Kulesh and Oshima 1989) and the mouse homolog, Endo B $\beta-1$ (Ichinose et al. 1988; Oshima et al. 1988), revealed that the first intron of $\mathrm{K} 18$ contains a stretch of $47 \mathrm{bp}$ that is identical in the mouse and human homologous genes (Fig. 3B, nucleotides 787-833). In contrast, the 5'flanking sequences of the two genes share no stretch of 


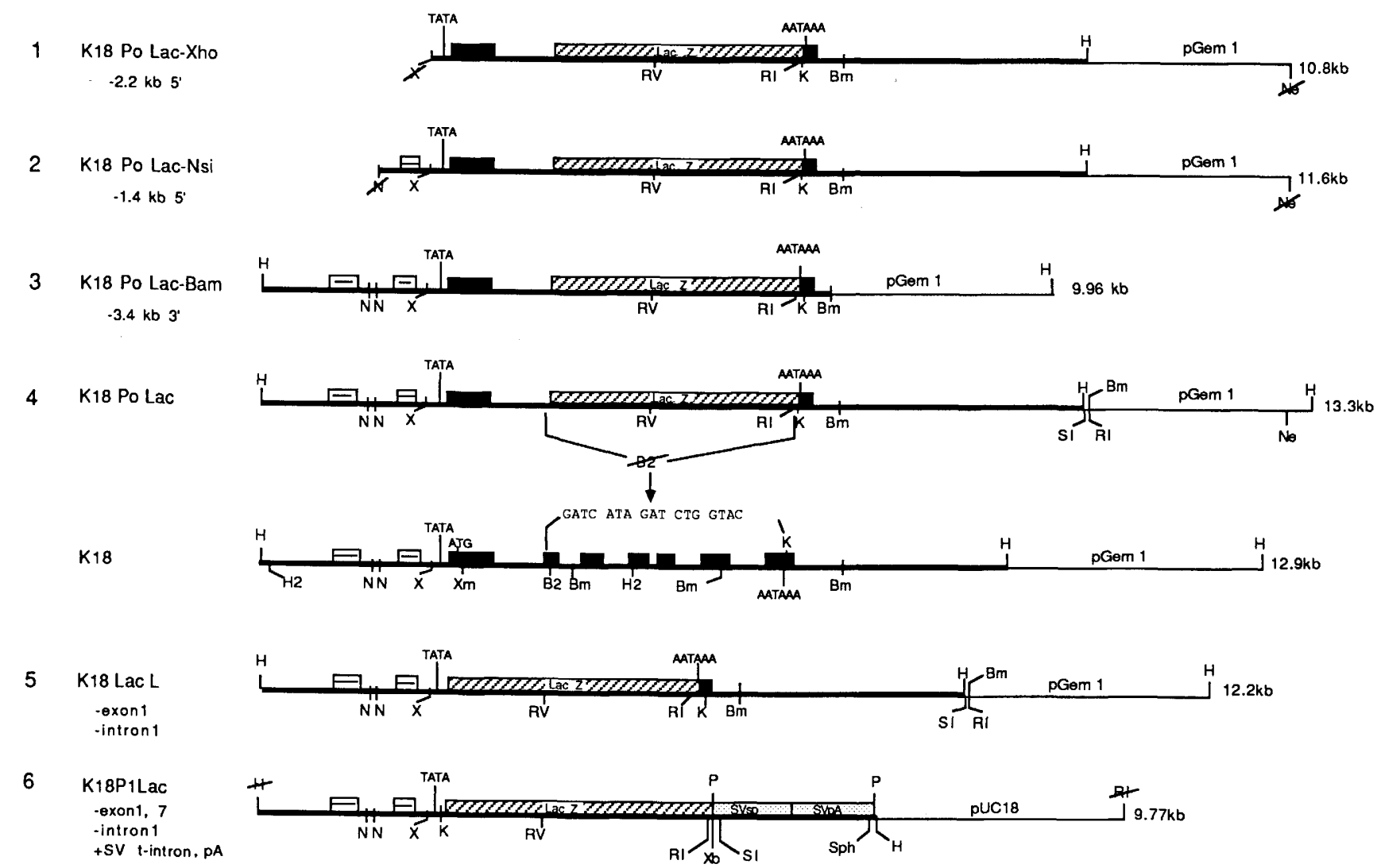

Figure 1. Structure of recombinant derivatives of the K18 gene. The genomic sequences of the K18 gene are shown by a thick black line; plasmid sequences are shown by a thin line. Exons of the K18 gene are shown by black boxes. Open boxes with lines show the position of $A l u$ repetitive sequences. The hatched boxes represent the bacterial $L a c Z$ gene coding for $\beta$-galactosidase. Shaded boxes in K18PlLac represent SV40 sequences containing the small t-antigen intron (SVsp) and polyadenylation signals (SVpA). TATA boxes and polyadenylation signals (AATAAA) of the K18 gene are indicated. The restriction enzyme sites indicated are: $(\mathrm{H})$ HindIII; $(\mathrm{N})$ NsiI; (X) XhoI; (RV) EcoRV; (RI) EcoRI; (K) KpnI; (Bm) BamHI; (B2) BglII; (Ne) NaeI; (H2) HincII; (SI) SalI; (Xb) XbaI; and (Sph) SphI. Sites destroyed during construction are indicated with crossed lines. The size of each construct is indicated at right. Differences from the $\mathrm{K} 18 \mathrm{POLac}$ starting vector are noted below the name of each vector.

identical nucleotides longer than 11 bp other than the two distal elements shown in Figure 3A. Embedded within the conserved intron sequence is a potential binding site for the AP-1 transcription factors, which include heterodimers of c-jun and c-fos (Angel et al. 1987; Lee et al. 1987; Chiu et al. 1988; Rauscher et al. 1988; Sassone-Corsi et al. 1988c). To test for enhancer activity, a 663-bp fragment of the first intron of K18 (Fig. 3B, nucleotides 505-1167) was placed both upstream and downstream of a CAT gene transcription unit driven by either $250 \mathrm{bp}$ of $5^{\prime}$-flanking sequence of the K18 gene (XKCATspA) or the herpes simplex virus thymidine kinase (HSV TK) promoter (TKCATspA) (Fig. 5). Both the normal orientation of the intron relative to the $\mathrm{K} 18$ gene (Is) and its inverted orientation (Ia) were tested. In addition, the intron sequence was placed upstream of a CAT gene that lacked a promoter (IsKOCAT and IaKOCAT). The results of transfecting these constructs into $\mathrm{Ltk}^{-}$ cells are shown in Figure 6.

When introduced into $\mathrm{Ltk}^{-}$cells, the truncated K18 promoter has relatively little activity (Fig. 6, XKCATspA). Addition of the intron fragment results in an enhancement of CAT expression in either the upstream or downstream position and in either orientation. However, it is clear that the normal (sense) orientation of the sequence downstream of the CAT transcription unit (XKCATIs) was most effective, resulting in a 27-fold increase in CAT expression. This sequence was also capable of activating the HSV TK promoter. Again, the sense orientation of the downstream position (Fig. 6, TKCATIs) was the most effective orientation. We conclude that the $\mathrm{K} 18$ first intron has enhancer activity, and such activity is not limited to its homologous promoter. However, this enhancer activity is sensitive to both position and orientation.

Activation of the K18 intron enhancer by c-jun and cfos in $F 9$ cells

Undifferentiated F9 EC cells do not transcribe the Endo $B \beta-1$ gene homolog of $\mathrm{K} 18$ and fail to express efficiently either the transfected $\mathrm{K} 18$ gene or $\mathrm{K} 18$ constructs $(\mathrm{Ku}-$ lesh and Oshima 1988) (Fig. 2B). The presence of a consensus AP-1-binding site within the conserved portion of 
Oshima et al.

A

Figure 2. Transient expression of $\beta$-galactosidase activity by $\mathrm{K} 18$ derivatives. $\{A\}$ Plates $(6-\mathrm{cm})$ of $\mathrm{Ltk}^{-}$cells initially containing $5 \times 10^{5}$ cells were transfected with a total of $10 \mu \mathrm{g}$ of DNA containing 1,3 , or $9 \mu \mathrm{g}$ of the indicated construct and $1 \mu \mathrm{g}$ of $\beta$-actin-CAT. The balance of DNA was pUC9. (Left) Numbers indicate the constructions shown in Fig. 1 . The $\beta$-galactosidase and CAT activities were determined on lysates prepared $48 \mathrm{hr}$ after the addition of DNA. Values represent the mean and standard deviation of the $\beta$-galactosidase activity per microgram of construct DNA divided by the CAT activity per microgram of $\beta$-actin-CAT DNA. Activity units of $\beta$-galactosidase and CAT were nanomoles of substrate cleaved or acetylated per milliliter of lysate per hour at $37^{\circ} \mathrm{C}$. The structures of the constructs are shown in Fig. 1 in the same relative order. (B) Approximately equal molar amounts of the indicated constructs and $\beta$ actin-CAT DNA $(3.7 \mu \mathrm{g})$ were transfected into the indicated cell lines. Amounts of $2.7 \mu \mathrm{g}$ of K18P0Lac-Bam, $3.6 \mu \mathrm{g}$ of K18P0Lac, $3.4 \mu \mathrm{g}$ of $\mathrm{K} 18 \mathrm{P} 1 \mathrm{LacL}$, or $2.7 \mu \mathrm{g}$ of K18P1Lac and, if necessary, pUC9 DNA, were used in a total of 7.3 $\mu \mathrm{g}$ for each $60-\mathrm{mm}$ dish. $\beta$-Galactosidase and CAT activities of lysates were measured and calculated per microgram of vector DNA. CAT activities were then normalized to the apparent transfection frequency of each cell line shown in Table 1. Values represent the ratios of $\beta$-galactosidase activity per microgram of DNA and the individual normalized CAT activity. Raw values of $\beta$-galactosidase activities for each cell line were similar to the normalized values shown. $\beta-$ Gal/CAT (AU/ug DNA)

1 K18PoLac-Xho
2 K18PoLac-Nsi
3 K18PoLac-Bam
4 K18PoLac
5 K18P, LacL

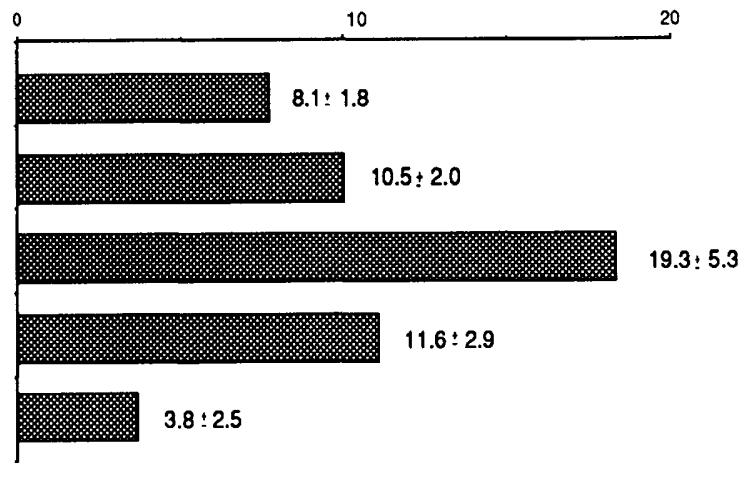

Relative $\beta$-Gal /CAT Activity

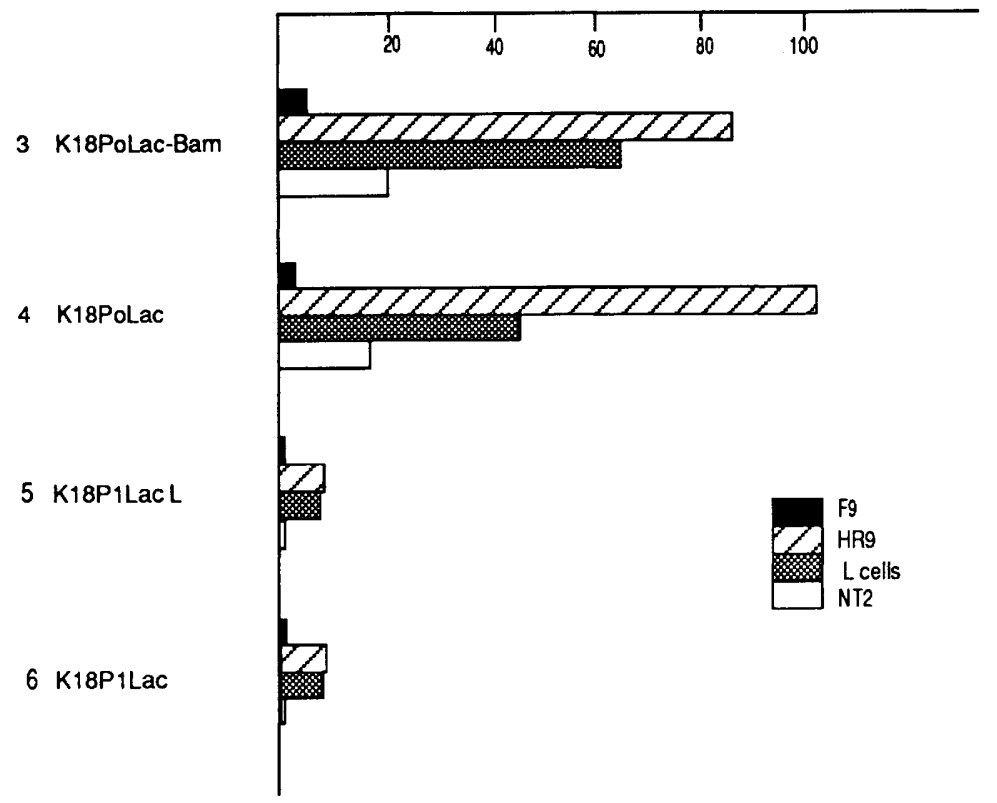

the first intron of $\mathrm{K} 18$ and the extremely low expression of both c-iun (Chiu et al. 1988) and c-fos (Muller and Wagner 1984; Ruther et al. 1985; Lockett and Sleigh 1987 ) in undifferentiated F9 cells suggested that K18 expression in F9 cells might be restricted by limiting amounts of these transcription factors. This hypothesis was tested by cotransfecting the XKCATIs construct into F9 cells along with either a c-jun expression vector or the c-fos gene to look for trans-activation of the XKCATIs construct. The results of these experiments are shown in Figure 7. The XKCATIs vector is significantly more active in F9 cells than the same vector lacking the intron (Fig. 7, columns A and D). However, the activity of XKCATIs is still very low in F9 cells. Cotransfection with increasing amounts of Rous sarcoma virus (RSV)-c-jun, a vector that expresses c-jun in F9 cells (Chiu et al. 1988), resulted in modestly increasing the activity of the reporter gene to a maximum of about fourfold (Fig. 7, columns F-I). This activation was not observed with a mutant c-jun expression vector (Angel et al. 1988; Chiu et al. 1988) (Fig. 7, column E) or with the reporter construct that lacked the first intron of K18 (Fig. 7, column B). Cotransfection of the XKCATIs reporter construct with increasing amounts of the c-fos gene resulted in increased CAT activity (columns $\mathrm{J}-\mathrm{N}$ ), which was linearly dependent on the amount of c-fos added. With the highest amount of c-fos used, the increase in CAT activity was $\sim 15$-fold (column N). Again, this activation was not observed when the reporter construct lacking the K18 intron fragment was used (column C). We conclude that both c-fos and, to a lesser extend, c-jun can activate the K18 promoter construct but only if the sequences of the first intron of $\mathrm{K} 18$ are included in the reporter gene. RNA protection experi- 


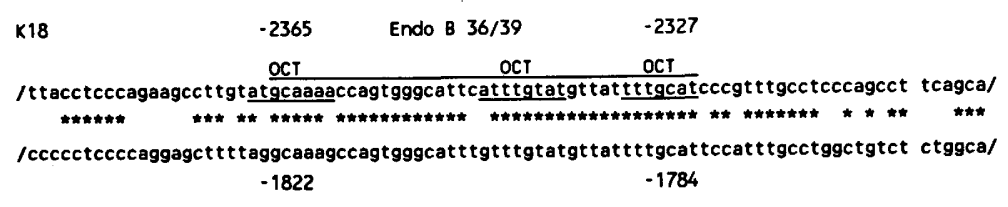

Endo $B$

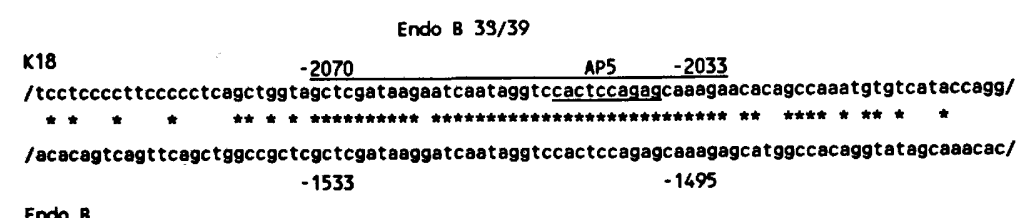

B. K18 INTRON 1

E2aE-C CCAAT, TATA AP5 CACCC-box

465

gtaaggggta 9gagggacct caactcccag ccttgtctga cctccaatt atacactect ttgectett ccgtcattcc ataaccaccc caaccctac

OCT

565 tccaccggga g9g9gttg9g catacct9ga tttccatccg cgcacctagc cacagggtcc ctaagagcag cagcagctag gcatgggagg gctctttccc

E4TFI, SV40 core MSV core

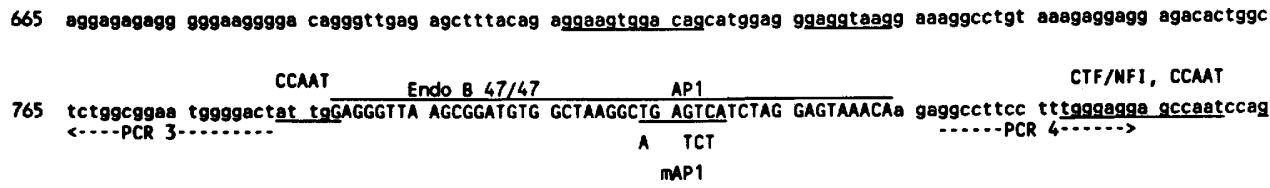

caccc-box

Endo B $13 / 13$

865 sqtgteg9g9 gcccagagtg accaggtgCa ctagggaaaa aATGCCAGGA GAGGgCCagg aagaggactt gttagtagcg actcacttct gggcaggcag

E2aE-C Endo B 16/17 CACCC-box

965 gccagccage tagccagcct getgaggett cccaagaggg gcagagtgct gggatctgGG AATCCAGGA AGGAGggaat ggggtgggge tagatgaaaa

caccc-boxes

1065 g9gataggtg tccagggaga gcctctgget attectg9ga ccaggaagtt ttcactagga tacataacac tttttacaca ctcaccccac ccatccctgg

AFP

1165 ctt tetattcatg gaacaaccte tetctacast cectccag

Figure 3. Similar noncoding sequences found in the K18 gene and the mouse Endo B $\beta-1$ gene. $(A)$ Comparison of two sequence elements located in the $5^{\prime}$-distal flanking regions of the two genes. Numbering of the sequence is relative to the major start of transcription as +1 (Ichinose et al. 1988; Kulesh and Oshima 1989). Stars indicate identical nucleotides. Conserved elements are overlined, with the number of matches indicated above the sequence. Possible regulatory motifs are underlined, with their designation above the sequence as noted previously (Kulesh and Oshima 1989). (B) Sequence of the first intron of K18. Three regions of the intron identical in mouse $\mathrm{K} 18$ (Endo $\mathrm{B} \beta-1$ ) and human $\mathrm{K} 18$ are in uppercase letters, with the match indicated above the sequence. The longest stretch of identical nucleotides is also overlined. The region of the intron that was synthesized by the PCR method for testing for enhancer activity is between the two oligonucleotide primer sites designated PCR 1 and PCR 2 and underlined with the broken lines and arrows. The two fragments that were synthesized separately and subsequently ligated to form an intron fragment with a 54-nucleotide deletion are defined by the PCR 1 and PCR 3 primers and the PCR 4 and PCR 2 primers. Note that the potential AP-1-binding site is found at nucleotide 808 within the 47-nucleotide identity found in the human and mouse K18 genes. The mAP1 designation indicates the nucleotides of the AP-1 site that were altered by site-specific mutagenesis. The K18 sequence shown is 7 nucleotides shorter than published (Kulesh and Oshima 1989) because of a typographical error in that reference, resulting in the duplication of 7 nucleotides starting at nucleotide 871 .

ments indicated that both the K18POLac-Bam and K18P0Lac-Xho constructs (Fig. 1, constructs 3 and 1, respectively/ were also trans-activated by c-fos, and the resulting mRNAs were initiated properly. Results for K18P0Lac-Bam are shown in Figure 4 (lanes 7-10).

The recent demonstration that c-jun and c-fos interact
(Chiu et al. 1988; Rauscher et al. 1988; Sassone-Corsi et al. 1988c) prompted us to transfect the XKCATIs reporter gene with both c-jun and c-fos (Fig. 7, columns O-V; Fig. 9B, column D). Although the combination of both c-jun and c-fos resulted in trans-activation of the CAT gene, the linear response with increasing c-fos was 
Oshima et al.

Figure 4. $S 1$ nuclease protection analysis of the $5^{\prime}$ ends of RNAs derived from cells transiently transfected with the K18POLac-Bam vector (Fig. 1, construct 3). A 480-nucleotide single-stranded DNA probe that overlaps with 240 nucleotides of the first exon of the K18 gene was used, as shown at bottom. Samples are as follows: (Lane 1) Size markers; (lane 2) probe alone; (lane 3) probe alone after nuclease digestion; (lane 4) $50 \mu \mathrm{g}$ of tRNA; (lane 5) $5 \mu \mathrm{g}$ of total RNA from NT2 human EC cells that express $\mathrm{K} 18$. Lanes $6-8$ received the digestion products of $50 \mu \mathrm{g}$ of total RNA from cells transiently transfected with $10 \mu \mathrm{g}$ of the $\mathrm{K} 18 \mathrm{POLac}-\mathrm{Bam}$ vector and an additional $5 \mu \mathrm{g}$ of pc-fos-3 DNA as indicated (+fos). Samples are as follows: (lane 6) HR9 cells; (lane 7) F9 cells; (lane 8) F9 cells, which also received the c-fos gene. A 17-hr autoradiographic exposure of the dried gel is shown. Lanes 9 and 10 represent a 3-day exposure of lanes 7 and 8 . (Left) The sizes of the markers are indicated in base pairs. The 240 -nucleotide fragment indicative of proper initiation is indicated at right.

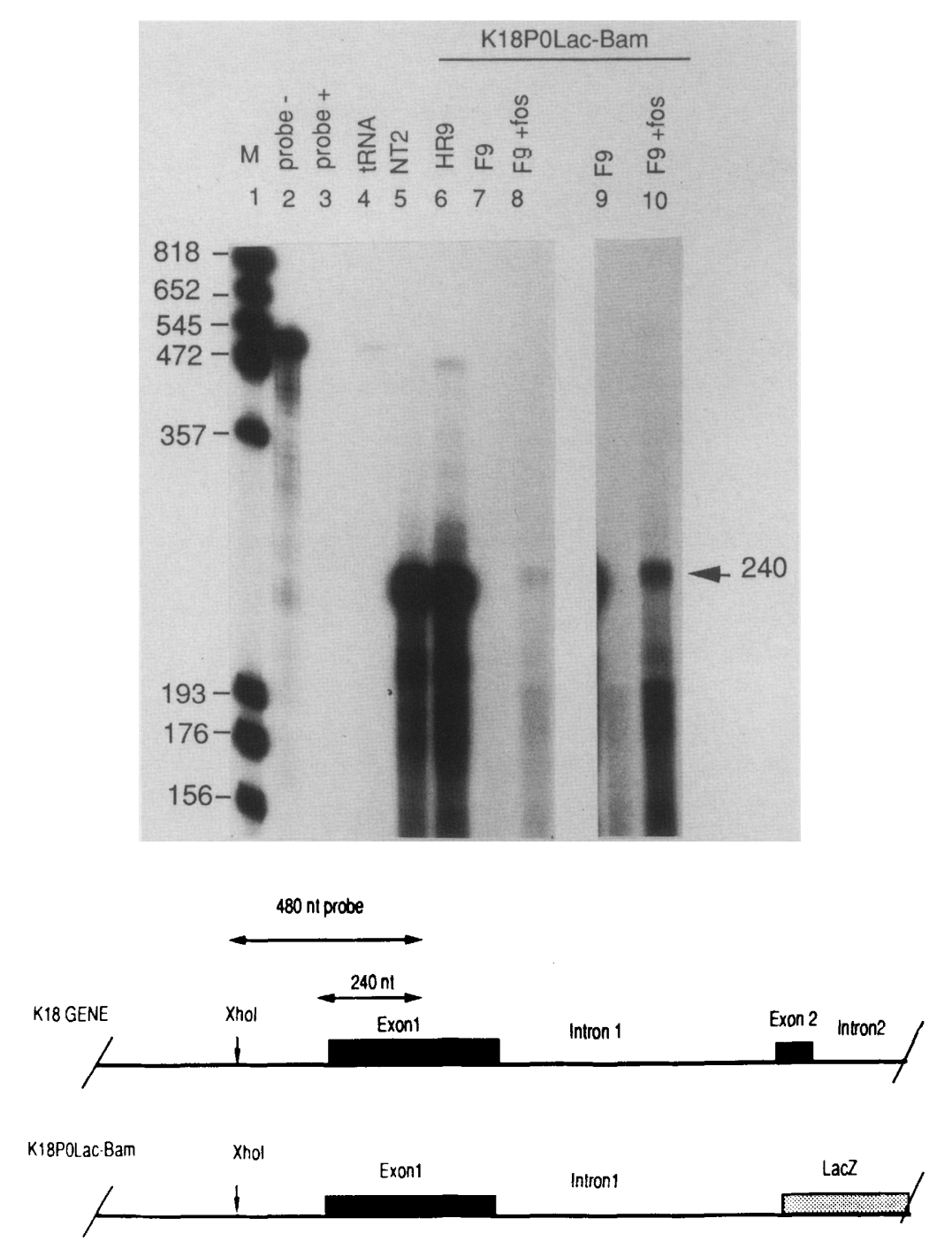

abolished when c-jun was also included. Of potential interest was the observation that when both oncogenes were included, the activation of XKCATIs was maximal at the same ratios of RSV-c-jun and c-fos (Fig. 7, columns $\mathrm{Q}$ and T). The activation of XKCATIs by c-jun and c-fos was neither synergistic nor additive.

In contrast to the activating effect of c-jun and c-fos on XKCATIs in F9 cells, the effects of the proto-oncogene expression plasmids in differentiated HR9 parietal endodermal cells were very modest (Fig. 8). Cotransfection with both the c-fos and c-jun expression vectors resulted in a 0.6-fold increase in CAT activity. The modest effect of c-jun and c-fos on XKCATIs in HR9 cells is consistent with the permissive state of these cells for K18 expression and the higher level of expression of c-jun and c-fos expected for these cells.

To identify the sequences necessary for the activation of the K18 enhancer in F9 cells more precisely, muta- tions of the intron sequence were introduced (Fig. 9A). Altered intron sequences were then inserted into the XKCAT vector. Deletion of $54 \mathrm{bp}$, including the 47-bp identity in the $\mathrm{K} 18$ and Endo $\mathrm{B} \beta-1$ gene introns, which contains the putative AP-1-binding site, abolished the ability of the intron sequence to be activated by either c-jun or c-fos (Fig. 9B, columns E-H; Fig. 9C, columns E and F). It also abolished enhancer activity in HR9 cells (data not shown). However, insertion of the 54-bp fragment, itself, back into the XKCAT vector was not sufficient to restore enhancer activity (data not shown). Thus, the conserved region is necessary but not sufficient for the activity of the intron. Insertion of the $54 \mathrm{bp}$ back into the context of the deleted intron sequence restored activity (Fig. 9C, lanes G and H). Alteration of 4 of the 7 nucleotides of the AP-1 site by site-specific mutagenesis abolished the ability of the intron sequence to be activated by c-fos in F9 cells (Fig. 9C, columns I and J) 


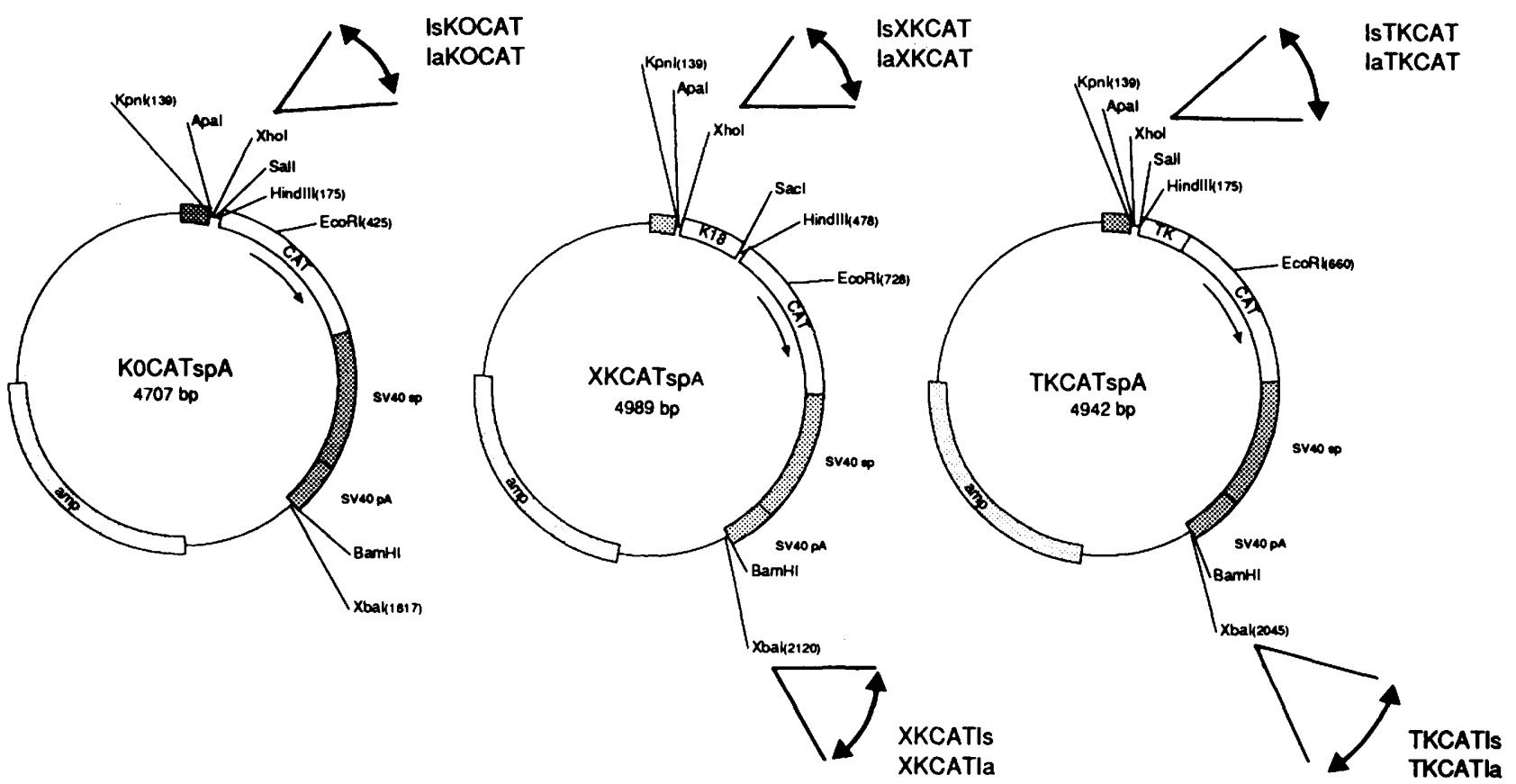

Figure 5. Restriction maps of CAT expression vectors. All vectors contain a 133-bp HpaI-BamHI fragment of SV40 containing termination signals upstream of a polylinker region and the CAT gene. The CAT gene is followed by the SV40 t-antigen intron (SV40sp) and polyadenylation signals (SV40pA). The ampicillin-resistance gene of the starting vector Bluescript $\mathrm{KSM}^{+} 3^{+}$is indicated (amp). The HSV TK promoter (TK) is inserted upstream of the CAT gene in TKCATspA and its derivatives. XKCATspA and its derivatives contain the truncated $\mathrm{K} 18$ promoter $(\mathrm{K} 18)(-251$ to +43$)$. The position of the 663-bp fragment of the first intron of K18 (I) $(+505$ to +1168$)$ is indicated by the double-headed arrows. The orientation of the fragment, which is the same as that found in the gene, is followed by an s, and the opposite orientation is followed by an a.

and abolished enhancer activity in HR9 cells /data not shown). This result identifies the AP-1 site as the target of the activation by c-fos in F9 cells.

\section{Activation of endogenous Endo B and Endo $A$ by $c$-fos}

The results of the transfection experiments presented above imply that the expression of $\mathrm{K} 18$ and its mouse homolog Endo B are restricted by the low level of c-fos within undifferentiated F9 cells. To determine whether supplementation of c-fos protein would result in the activation of the endogenous Endo B $\beta-1$ gene, a previously characterized derivative of $F 9$ cells, designated $76 / 21-3$, was utilized. This cell line contains a c-fos expression construct regulated by the human metallothionein promoter. It has a very low basal level of expression of fos. Treatment with cadmium results in a large and rapid increase in c-fos mRNA and protein (Ruther et al. 1985). Treatment of this cell line with cadmium results in increased Endo B and Endo A protein synthesis within $8 \mathrm{hr}$ (Fig. 10A,B, lanes 6) and was highest after $16 \mathrm{hr}$ (the maximal duration due to the toxicity of cadmium). In comparison, increased expression of Endo B and Endo A mRNA and protein is detectable in retinoic-acid-treated F9 cells only after $\sim 48 \mathrm{hr}$ (Oshima 1982; Tabor and Oshima 1982; Trevor and Oshima 1985|. The increased synthesis of the two proteins correlates roughly with the reported time of maximal expression of fos after cad- mium treatment (Ruther et al. 1985). Increased Endo B and Endo A expression in 76/21-3 cells was dependent on exposure to the metal ion (Fig. 10A and C, lanes 7). Treatment of F9 parental cells with cadmium did not result in increased Endo B synthesis (Fig. 10A, lane 5). Immunoprecipitation with laminin antiserum showed that cadmium treatment did not change the expression of the laminin A or B chains in either $76 / 21-3$ or F9 cells (data not shown). This latter result is consistent with the original reports on the effect of c-fos on the differentiation of F9 cells (Muller and Wagner 1984; Ruther et al. 1985). It is clear that the genes for Endo B and laminin, both of which are expressed in differentiated derivatives of $\mathrm{F} 9$ cells, are regulated differently. In contrast, the induction of both Endo A and Endo B synthesis reinforces the presumption that the genes for these complementary subunits share regulatory mechanisms.

\section{Discussion}

The activation of $\mathrm{K} 18$ constructs in F9 cells that are cotransfected with plasmids expressing either c-jun or c-fos (Fig. 7) is consistent with the view that K18 may be limited by the absence of these transcription factors in F9 cells. Both factors are known to be either absent or extremely low in abundance in undifferentiated F9 cells (Muller and Wagner 1984; Ruther et al. 1985; Lockett and Sleigh 1987; Chiu et al. 1988). Both are induced after 
Oshima et al.

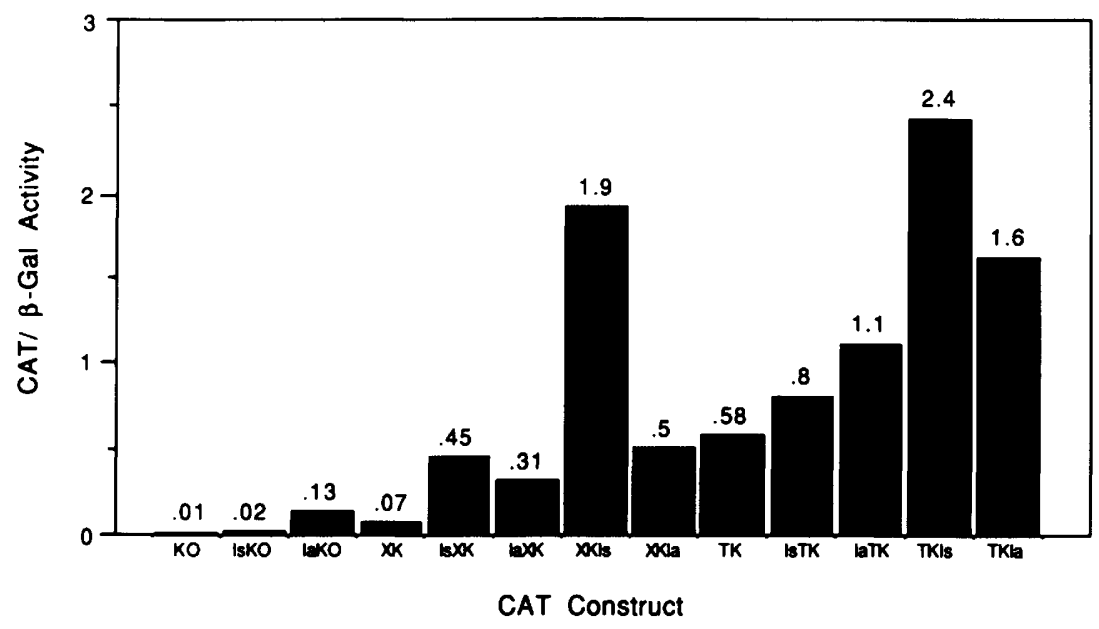

Figure 6. Enhancer activity of the $\mathrm{K} 18$ intron 1 fragment. Dishes $(6-\mathrm{cm})$ of $\mathrm{Ltk}^{-}$cells were transfected with $2.1 \mu \mathrm{g}$ of the indicated CAT constructs and $5 \mu \mathrm{g}$ of $\beta$-actin-LacZ (approximately equal molar amounts of two vectors) in two separate experiments. CAT activity (picomoles of chloramphenicol acetylated per milliliter of lysate per hour at $37^{\circ} \mathrm{C}$ ) per microgram of CAT plasmid CNA was divided by $\beta$-galactosidase activity per microgram of LacZ DNA. (Bottom) Values of the individual experiments. (Top) The average values of the two experiments in graphic form. The CAT designation is deleted from the abbreviated names of the constructs (top).

\begin{tabular}{lllll}
\multicolumn{5}{c}{ CAT/B-Ga1 ACtivity } \\
CAT Construct & EXp. 1 & EXp.2 & Avg. & Fold Increase \\
\hline KOCATspA & 0.02 & 0.00 & 0.01 & - \\
IsKOCAT & 0.02 & 0.02 & 0.02 & - \\
IaKOCAT & 0.13 & 0.13 & 0.13 & - \\
\hline XKCATspA & 0.10 & 0.03 & 0.07 & 1.0 \\
IsXKCAT & 0.41 & 0.48 & 0.45 & 6.4 \\
IaXKCAT & 0.48 & 0.15 & 0.31 & 4.4 \\
XKCATIs & 1.95 & 1.85 & 1.90 & 27.1 \\
XKCATIa & 0.60 & 0.40 & 0.50 & 7.1 \\
\hline TKCATspA & 0.43 & 0.74 & 0.58 & 1.0 \\
IsTKCAT & 0.98 & 0.69 & 0.83 & 1.4 \\
IaTKCAT & 1.00 & 1.33 & 1.15 & 2.0 \\
IKCATIs & 3.10 & 1.69 & 2.39 & 4.1 \\
IKCATIa & 1.53 & 1.73 & 1.63 & 2.8
\end{tabular}

treatment of F9 cells with retinoic acid (Mason et al. 1985; Lockett and Sleigh 1987; R. Chiu and M. Karin, pers. comm.|, a condition that results in the expression of mouse K18 (Oshima 1981, 1982). In addition, the expression of antisense c-fos RNA appears to inhibit the differentiation of F9 cells, including the expression of keratin-related filaments (Edwards et al. 1988). The modest activation by c-jun, alone, may reflect a limitation imposed by the concentration of c-fos. In contrast, the near linear response of the reporter gene on cotransfected $\mathrm{c}$-fos leads to speculation that c-fos expression may induce c-jun. Previously, it has been shown that expression of c-fos in F9 cells leads to the appearance of partially differentiated cells that express mouse K8 and a complementary type I keratin partner, most likely mouse K18 (Muller and Wagner 1984). However, the expression of c-fos alone is not sufficient to induce the full complement of differentiation markers (Ruther et al. 1985). The results reported here suggest that the in- creased expression of keratins found in F9 cells transfected with c-fos may reflect a direct interaction of c-fos and c-jun with the mouse K18 gene. This interpretation is reinforced by the observed rapid activation of endogenous mouse $\mathrm{K} 18$ (Endo $\mathrm{B}$ ) and $\mathrm{K} 8$ (Endo A) synthesis by c-fos (Fig. 10). The increase in Endo B and Endo A expression in cadmium-treated $76 / 21-3$ cells was much faster than that seen previously for retinoic-acid-treated F9 cells and appears consistent with the kinetics of synthesis of c-fos mRNA and protein in 76/21-3 cells (Ruther et al. 1985).

The demonstrated interaction between jun-related proteins and c-fos (Chiu et al. 1988; Nakabeppu et al. 1988; Rauscher et al. 1988; Sassone-Corsi et al. 1988b,c), the positive autoregulation of c-jun by its own product (Angel et al. 1988), and the negative regulation of c-fos by its own product (Sassone-Corsi et al. 1988c) provide multiple possibilities for modifying the expression of K18. The lack of additive effects seen when both c-jun 


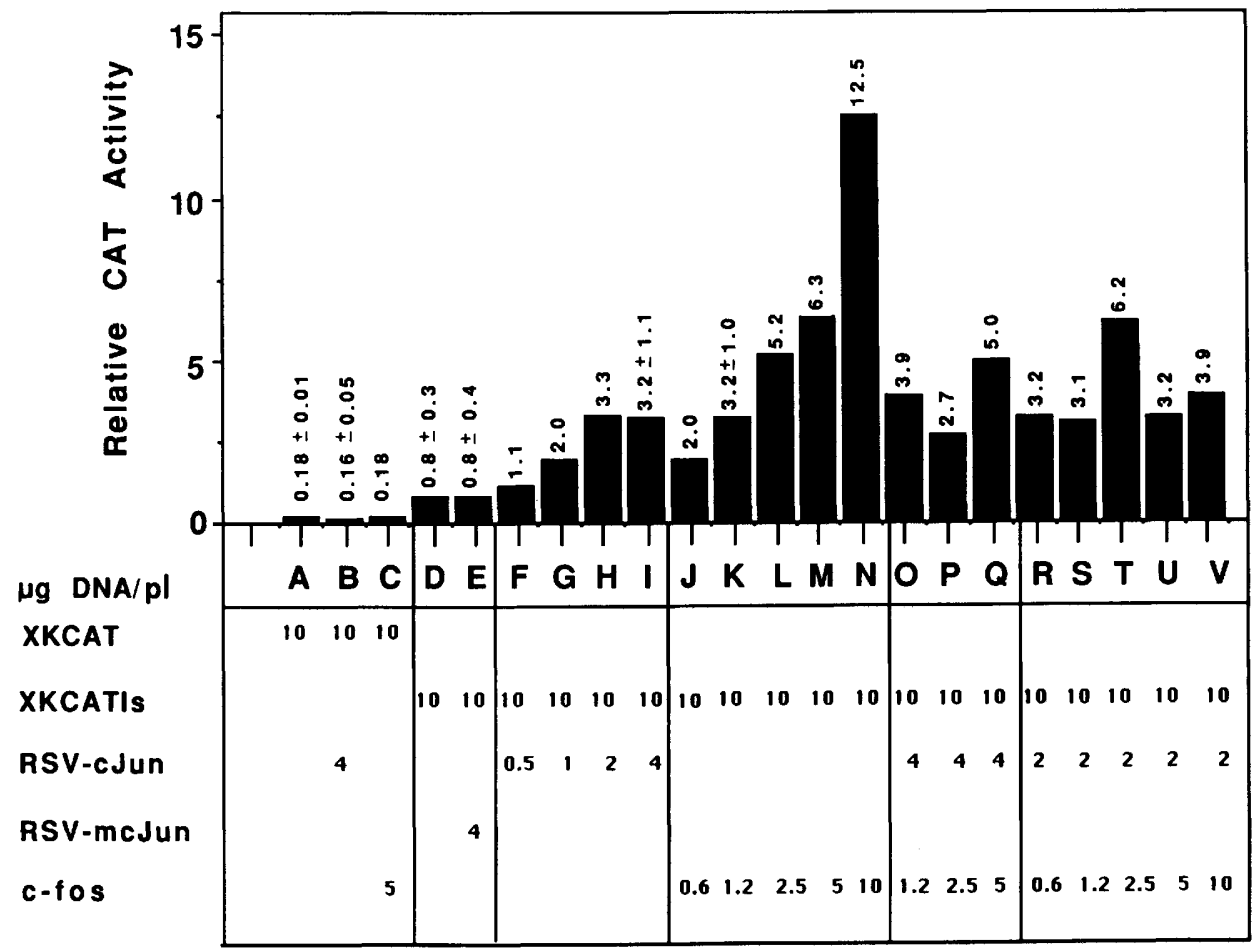

Figure 7. Activation of the XKCATIs construct in F9 cells by c-jun and c-fos. Dishes $(9-\mathrm{cm})$ of F9 cells, which initially contained $1.5 \times 10^{6}$ cells, were transfected with the amounts of DNA indicated below each column, along with $1.5 \mu \mathrm{g}$ of $\beta$-actin-LacZ and pUC9 DNA, for a total of $20 \mu \mathrm{g}$ of DNA per plate. Values shown in the graph represent the averages of duplicate dishes, except for those shown with standard deviations, which are the averages of three or more plates in at least two separate experiments. CAT activities $(\times 10)$ were normalized to $\beta$-galactosidase activity, as in Fig. 6 .

and $c$-fos are cotransfected with the $\mathrm{K} 18$ constructs may be due to the complicated interaction of these two transcription factors or even similar related factors (Hai et al. 1988; Nakabeppu et al. 1988; Zerial et al. 1989/. One speculative alternative to the direct activation of the AP-1 site by c-fos and c-jun is the possible negative regulation at the AP-1 site by junB or junD. Relief of such repression could be effected by competition of jun $\mathrm{B}$ or junD with c-fos and c-jun during heterodimer formation. The observation that particular ratios of the c-jun and c-fos gene were most effective in activating expression of the $\mathrm{K} 18$ reporter gene may be hints of the complicated interaction between the products of endogenous and exogenously coded products.

It remains to be determined whether c-fos and members of the c-jun family are the only limiting factors for the expression of K18 in EC cells. The induction in F9 cells of $\mathrm{K} 18$-directed $\beta$-galactosidase mRNA by cotransfection with c-fos results in much less RNA than that found in differentiated cells transfected with the same reporter construct (Fig. 4). Although the interaction of c-fos and c-jun with each other and the AP-1binding site may be necessary for expression of $\mathrm{K} 18$, additional steps may also be involved in the normal induction of mouse K18. There are multiple reports of negative regulatory activities in F9 cells /Gorman et al. 1985; Borrelli et al. 1986; Lenardo et al. 1989; Onclercq et al. 1989; Young et al. 1989). Recently, it has been sug- gested that the mouse $\mathrm{K} 8$ gene (Endo $\mathrm{A} \alpha-1$ ) is negatively regulated by trans-acting factors that also recognize SV40 and polyomavirus sequences (Onclercq et al. 1989).

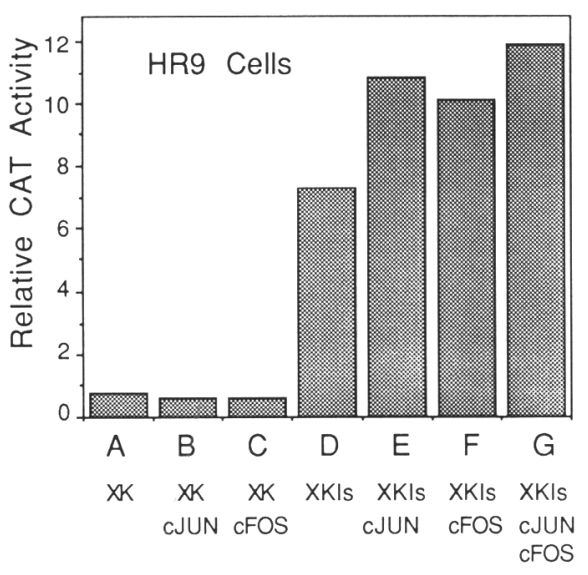

Figure 8. c-jun and c-fos have relatively little stimulatory activity on XKCATIs in HR9 parietal endodermal cells. HR9 cells were transfected with $10 \mu \mathrm{g}$ of either XKCAT or XKCATIs and $1.5 \mu \mathrm{g}$ of $\beta$-actin-LacZ DNAs. As indicated, the cells also received $2 \mu \mathrm{g}$ of RSV-c-Jun (cJUN) and/or $2 \mu \mathrm{g}$ of pc-fos-3 (cFOS) plasmid DNAs and carrier pUC9 DNA, for a total of $20 \mu \mathrm{g}$ per plate. Values were normalized to $\beta$-galactosidase activity, as in Fig. 7. Values represent the average of duplicate dishes. 
Figure 9. Mutagenesis of the K18 intron fragment. $(A)$ Schematic maps of the alterations of the K18 intron. The dark line represents $\mathrm{K} 18$ intron 1 sequences. The stippled box indicates the sequences deleted in the Ids fragment. Restriction sites are: (X) XbaI; (B) BamHI; and (Bg) BgIII. Sequences from 783 to 836 of the K18 intron (Is) were replaced by a BamHI site generating the Ids fragment. Synthetic double-stranded oligonucleotides corresponding to either the wild-type sequence or one altered at $4 \mathrm{bp}$ of the AP-1-binding site (mAPl) were inserted into the BamHI site of Ids to generate IB and IBmAP1. The wild-type AP-1 site TGAGTCA was changed to AGATCTA in mAP1. All fragments were inserted into the XKCATspA vector in the same orientation as the normal gene and tested by transient transfection. Values represent the average of duplicate dishes, as in Fig. 7. (B) F9 cells were transfected with $10 \mu \mathrm{g}$ of either XKCATIs (XKIs) or XKCATIds (XKIds) plasmids. As indicated, the cells also received $2 \mu \mathrm{g}$ of RSV-c-Jun and/or $2 \mu \mathrm{g}$ of pc-fos-3 plasmid DNAs. In addition, all plates received $1.5 \mu \mathrm{g}$ of $\beta$-actin- $L a c Z$. Values represent the average of duplicate dishes of cells, as described for Fig. 7. Note that constructs containing the deleted intron (XKIds) are inactive and are not activated by either c-fos or c-iun. $(C)$ F9 cells were transfected with $10 \mu \mathrm{g}$ of $\mathrm{XKCAT}(\mathrm{XK})$ that contained no intron sequence, XKCATIs (XKIs), XKCATIds (XKIds), XKCATIB (XKIB), or XKCATIBmAP1 (XKIBmAP1) and $1.5 \mu \mathrm{g}$ of $\beta$-actin-LacZ plasmid DNAs. Columns marked with plus signs $(+\mid$ also received $5 \mu \mathrm{g}$ of pc-fos-3 (cFOS) DNA. Additional pUCl 8 plasmid DNA was added, if necessary, to a total of $16.5 \mu \mathrm{g}$ of DNA per plate.

However, deletion of the $3^{\prime}$-flanking sequences, $5^{\prime}$ flanking sequences, or the first exon and intron did not result in increased expression in F9 EC cells (Fig. 2B; additional data not shown). Thus, it appears unlikely that a specific negative regulatory element is solely responsible for the lack of expression of $\mathrm{K} 18$ constructs in EC cells. Furthermore, F9 cells appear to lack DNA-binding proteins that recognize the nuclear factor (NF1) sequence motif (Speck and Baltimore 1987), which is found within the first intron of K18. The observation that a synthetic 54-bp fragment containing the 47-bp $\mathrm{K} 18$ intron identity cannot substitute for the full intron fragment indicates that the efficient expression of $\mathrm{K} 18$ gene requires the interaction of additional intron elements with their cognate proteins. The trans-activation of $\mathrm{K} 18$ constructs by c-jun and c-fos observed in transient assays does not rule out the possibility of further activation or stabilization by additional factors during the normal induction of the endogenous gene.

In addition to the possible roles of c-jun and c-fos in limiting expression of $\mathrm{K} 18$ in EC cells, these transcription factors could be involved in the modulation of $\mathrm{K} 18$
A

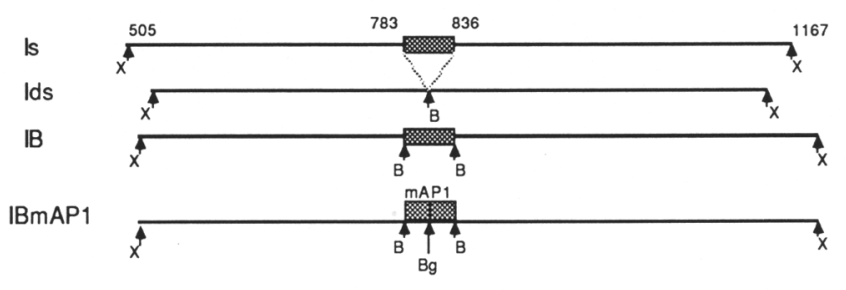

B

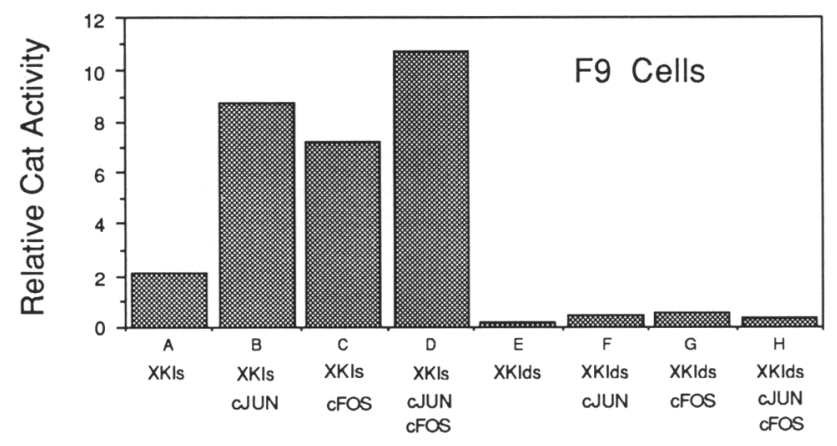

C

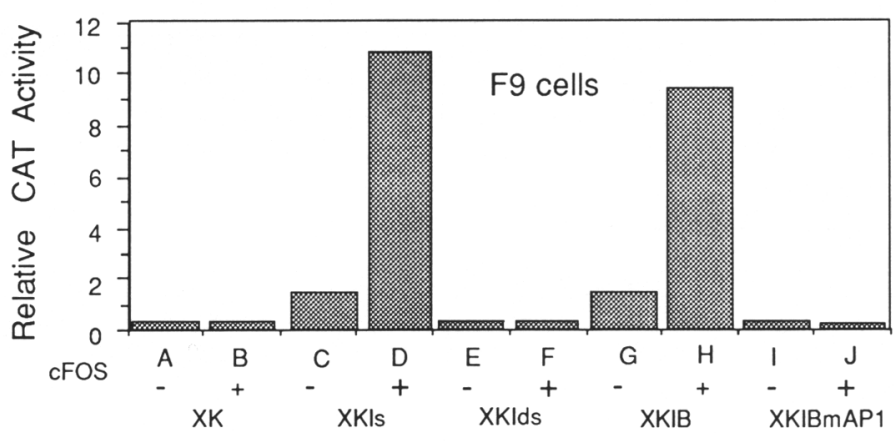

expression in differentiated cells. In cultured HR9 parietal endodermal cells, the expression of additional c-jun and c-fos has little effect on the expression of the K18 reporter construct. This is consistent with our observation that phorbol ester treatment of HR9 cells fails to increase the synthesis of mouse K18 and K8 (R. Oshima, unpublished results|, because response to phorbol ester is mediated by the AP-1 site. However, there are a number of examples of dramatic modulations of K18 expression, such as the dramatic increase in K18 synthesis in explants of primary liver cells (Ben-Ze'ev et al. 1988). The well-documented sensitivity of c-fos expression to a large variety of agents provides many possibilities for the modulation of $\mathrm{K} 18$ expression if $\mathrm{c}$-fos is needed for optimal transcription of K18.

There are now multiple examples of enhancers located within introns (e.g., Rossi and de Crombrugghe 1987; Burbelo et al. 1988; Kawamoto et al. 1988; Karpinski et al. 1989). The enhancer activity associated with K18 differs from that found for a bovine epidermal keratin in both its location relative to the start of transcription and its cell-type specificity (Blessing et al. 1989). This rein- 

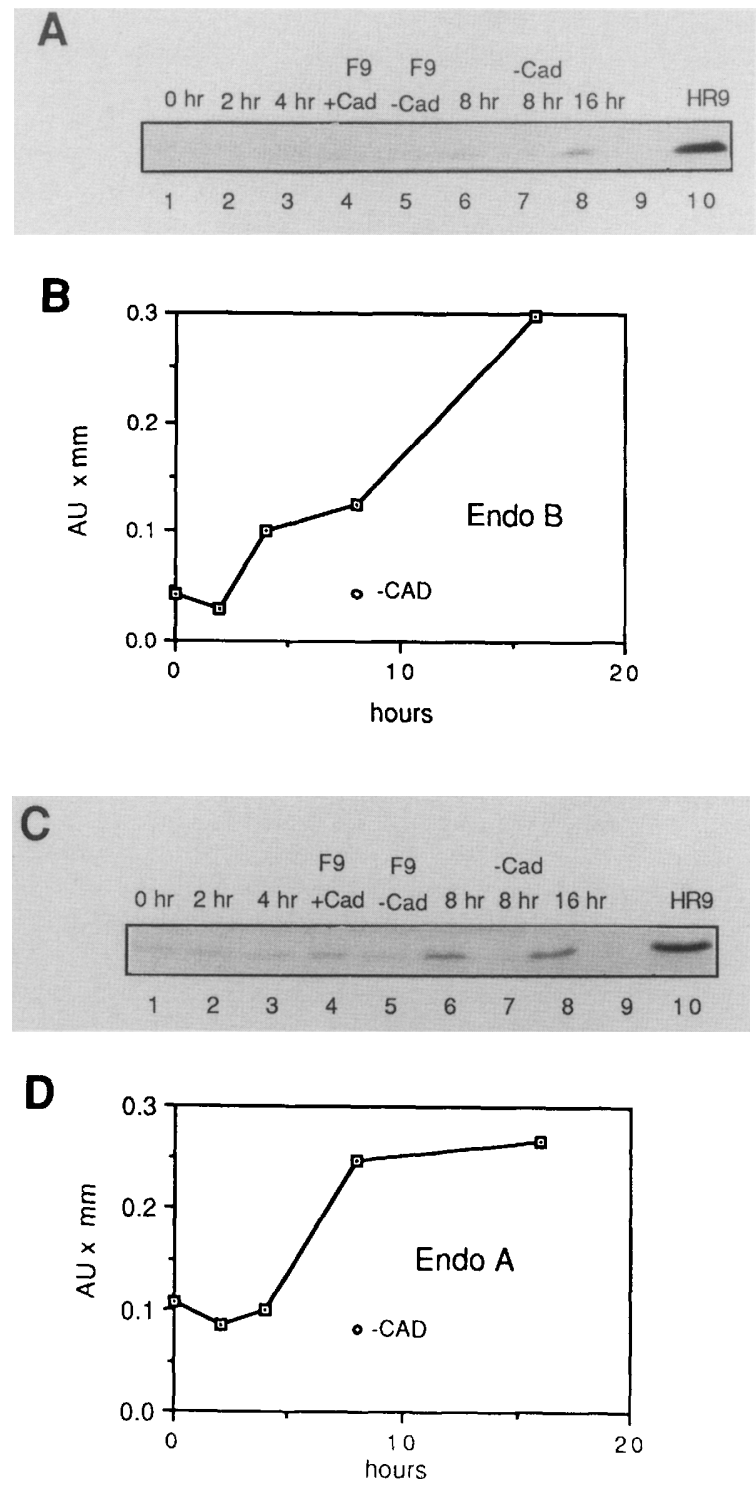

Figure 10. Cadmium induction of Endo $B$ and Endo $A$ in 76/21-3 cells. 76/21-3 cells and F9 cells were incubated for the indicated time in normal medium in the presence or absence of $5 \mu \mathrm{M}$ cadmium chloride. Cells were then labeled for $30 \mathrm{~min}$ and immunoprecipitated with Endo $\mathrm{B}(A$ and $B)$ or Endo $\mathrm{A}(C$ and $D)$ antisera. The precipitates were resolved in gels containing SDS and detected by fluorography (panels $A$ and $C) .(A$ and $C$ ) Samples in lanes $1,2,3,6$, and 8 are derived from $76 / 21-3$ cells exposed to cadmium for the indicated period. Lane 7 shows the result of precipitating cells that received medium without cadmium. Lanes 4 and 5 show the results of precipitating control F9 cells that received either normal or cadmium-containing medium. Marker immunoprecipitate of Endo B or Endo A from HR9 parietal endodermal cells that constitutively synthesize the two proteins is shown in lane 10 . Lane 9 was intentionally left empty. Densitometric values for 76/21-3 samples are shown in $B$ and $D$.

forces the view that whereas the large intermediate gene family codes for closely related proteins, individual members are regulated quite differently.
In summary, we have identified an enhancer activity within the first intron of the K18 gene that appears not to be cell-type-specific but functions through the interaction of transcription factors with members of the iun and fos families. Low levels of these proto-oncogenes may, at least in part, limit the expression of the gene in undifferentiated EC cells and by analogy in early embryonic cells.

\section{Materials and methods}

The K18P0Lac expression vector was constructed as outlined in Figure 1. A minigene intermediate was made by cleaving the pGC1835 plasmid, which contains the K18 gene /Kulesh and Oshima 1988), with BgIII and KpnI and closing the plasmid with the double-stranded synthetic oligonucleotide indicated in Figure 1. A BamHI fragment containing the $L a c Z$ gene derived from the pJ3 plasmid was inserted into the new BgIII site to create an open reading frame that fused the beginning of the second $\mathrm{K} 18$ exon to the eighth codon of the LacZ gene. The expected transcript would use the $\mathrm{Kl} 8$ polyadenylation signal. The plasmids K18P0Lac-Xho and K18P0Lac-Nsi were generated by cleaving K18P0Lac with either XhoI or NsiI, respectively, and with NaeI. The blunted ends were then closed together. The two resulting vectors contain $251 \mathrm{bp}$ and $1076 \mathrm{bp}$ of K18 5'-flanking sequences, respectively. K18P0Lac-Bam was formed by deleting the $3.4-\mathrm{kb}$ BamHI fragment of K18POLac, which contains sequences $3^{\prime}$ to the K18 gene. The K18P1Lac vector contains the $5^{\prime}$-flanking region and $43 \mathrm{bp}$ of noncoding sequences of the first exon of K18 fused to the BglII fragment of p)3. The latter fragment contains $14 \mathrm{bp}$ of the $5^{\prime}$-noncoding region and the first and second codons of the Moloney murine leukemia virus (MoMLV) env gene fused to the eighth codon of the LacZ gene. (C. Cepko, pers. comm. and confirmed by DNA sequencing). A 1424-bp PstI fragment from pSV2Neo containing the t-antigen intron and the polyadenylation and termination signals of SV40 is positioned downstream of the LacZ gene. The K18P1LacL vector was constructed by replacing the 2.57-kb XhoI-EcoRV fragment of the K18POLac vector, which includes the first exon and the first intron of $\mathrm{K} 18$ and the 5 ' end of the LacZ gene, with the 1.44-kb XhoI-EcoRV fragment of K18P1Lac.

The basic CAT expression vector KOCATspA was constructed by first cloning the 1630-bp HindIII-BamHI fragment of pSV2CAT into the compatible sites of Bluescript $\mathrm{KSM}^{+}{ }^{+}$. The resulting vector was cleaved with $K p n I$ and $A p a I$ and ligated to a staggered double-stranded oligonucleotide. The sequence of one strand of the oligonucleotide was AAGATCTGGTACCGGGCC. The second oligonucleotide overlapped with the first sequence to create compatible ends for KpnI and ApaI. The 133-bp HpaI-BamHI fragment of pSV2CAT that contains SV40 termination and polyadenylation signals was cloned into the unique $B g I I I$ site of the synthetic oligonucleotide with the use of a BamHI linker for the HpaI end, thus creating KOCATspA. SV40 termination signals upstream of the transcription units decrease the potential background that results from readthrough transcription from inappropriate initiations within plasmids sequences. To construct XKCATspA, a 3' exonuclease III deletion of the K18 gene in phage M13mp19 was cloned as an XhoI-EcoRI fragment into KOCATspA. The 3' EcoRI site of the Kl8 deletion and the 5' HindIII site of the CAT gene were blunt-end-ligated. The HSVTK promoter was isolated from F101TKCATpA4 (Linney and Donerly 1983|. The F101 mutant polyoma enhancer was first deleted by digestion with $\mathrm{XbaI}$ and self-ligation. The HindIII 
fragment containing the TK promoter was then inserted into KOCATspA to create TKCATspA.

For testing sequences of the first intron of $\mathrm{K} 18$ for enhancer activity, a 663-bp fragment of the 742-bp intron was synthesized by polymerase chain reaction (PCR) methods (Saiki et al. 1988). The sequence of the amplified fragment was confirmed by DNA sequencing. The primers started with $\mathrm{CC}$ and then contained either an XbaI or XhoI site followed by 15 or $19 \mathrm{nu}$ cleotides of the intron sequence (Fig. 3B, PCR 1 and PCR 2). The intron sequence of the $5^{\prime}$ primer started at nucleotide +505 (Kulesh and Oshima 1989), whereas the complementary sequence of the $3^{\prime}$ primer ended at nucleotide +1167 . The amplified fragments were digested with either $\mathrm{XhoI}$ or $\mathrm{XbaI}$ and inserted into the unique $X$ hol site $5^{\prime}$ of the K18 and TK promoter sequences of XKCATspA and TKCATspA, respectively, or into the unique $X b a I$ site $3^{\prime}$ of the CAT gene and SV40 polyadenylation signals of the same vectors (Fig. 5). The effective deletion of a portion of the K18 first intron (783-837 bp) was constructed by synthesizing two fragments of the intron by PCR. One primer of each set (Fig. 3B, PCR 3 or PCR 4) started with CCGGATCC to create $B a m H I$ sites. The second primer of each set (Fig. 3B, PCR I or PCR 2) contained terminal XbaI sites. After synthesis, the two fragments were digested with $B a m H I$ and ligated together. After subsequent digestion with $X b a I$, the appropriate size fragment was gel-purified and inserted into the XbaI site of XKCATspA to create XKCATIds (Fig. 9). After verification by sequencing, the deleted intron fragment was moved to a XKCATspA vector, which had been modified to remove the unique $B a m H I$ site by Klenow treatment and self-ligation. The site-specific mutagenesis of the AP-1 site was accomplished by synthesizing complementary oligonucleotides (Fig. 3B, nucleotides 783-826) with additional BamHI-compatible ends. The mutant AP-1 oligonucleotides differed from the wild-type sequence at four positions of the AP-1 site, as indicated in Figure 3B, to create a BglII site. The annealed synthetic oligonucleotides were inserted into the BamHI site of the deleted intron (Fig. 9A, IB and IBmAPl) of the modified XKCATIds vector that contained only a single BamHI site. The inserted fragments were sequenced to verify the orientation and fidelity of the synthetic oligonucleotides.

To standardize the transfection of different plasmids and different cell lines, the CAT and LacZ genes were inserted into the human $\beta$-actin expression vector $\mathrm{pH} \beta \mathrm{APr}-1-\mathrm{Neo}$ (Gunning et al. 1987). The 785-bp HindIII-XhoII fragment of KOCATspA containing the CAT gene-coding sequences and ending $194 \mathrm{bp}$ downstream of the putative CAT translational termination codon was inserted between the unique HindIII and BamHI sites of pHßAPr-1-Neo to create $\beta$-actin-CAT. The LacZ gene was cloned as a $B g I I I$ fragment from $\mathrm{pJ} 3$ into the unique $B a m H I$ site of pH $\beta A P r-1-N e o$, resulting in $\beta$-actin-LacZ. The expression vectors for $c$-jun and a mutant c-jun (containing a frameshift within the DNA-binding domain/ and driven by the RSVLTR (long terminal repeat) promoter (RSV-c-jun and RSV-mcjun) (Angel et al. 1988) were kindly provided by Robert Chiu and Michael Karin (University of California, San Diego, La Jolla, CA). The pc-fos-3 plasmid containing the entire mouse c-fos gene (Curran et al. 1983; Miller et al. 1984) was provided by Steven Edwards and Eileen Adamson (La Jolla Cancer Research Foundation, La Jolla, CA).

DNA was introduced into cells by the calcium phosphate precipitate method and assayed for CAT activity and $\beta$-galactosidase activity as described by Gorman (Gorman 1985). In 6-cm dishes, $5 \times 10^{5}$ cells were plated, whereas $1.5 \times 10^{6}$ cells were plated when $9-\mathrm{cm}$ dishes were used. A total of either 7 or $20 \mu \mathrm{g}$ of DNA was used for 6- and 9-cm dishes, respectively. DNA precipitates were added the day after plating, and all lysates were prepared $48 \mathrm{hr}$ after addition of the DNA precipitate. The protease inhibitor aprotinin (Sigma Chemical) was added to all lysates (0.3 trypsin inhibitor $\mathrm{U} / \mathrm{ml}$ lysate) because preliminary experiments indicated that the linear portion of the $\beta$-galactosidase assay was extended with its addition and the activity of CAT was stabilized in some lysates. In all experiments, the activity of either the CAT or LacZ genes was normalized to the activity of the same lysate of the appropriate cotransfected $\beta$ actin vector. The large variability in the activity of the reporter genes from experiment to experiment and even from plate to plate (see Table 1) was thus greatly reduced. However, the activity of the CAT plasmid was not the same in every cell type, as shown in Table 1 . In a survey of several different CAT expression vectors, the activity of the $\beta$-actin-CAT vector was highest and most reproducible in most cell types. However, in the case of F9 cells, standardization to $\beta$-actin-CAT leads to artificially high values because of the relatively low activity of this construct. To compare different cell lines, the individual cat activities were first normalized to the average value found for $\beta$-actin-CAT in independent experiments shown in Table 1 . The $\beta$-galactosidase activity per microgram of plasmid DNA was then divided by the normalized CAT activity.

S1 nuclease protection analysis of RNA was performed as described previously (Kulesh and Oshima 1988) by using a 480nucleotide probe that overlaps with the K18 first exon by 240 nucleotides. Both authentic K18 mRNA and RNAs derived from properly initiated vectors containing the first exon protect the same portion of the probe.

The antisera and the immunoprecipitation methods have been described previously (Oshima 1981, 1982). The 76/21-3 cells (Ruther et al. 1985) were obtained from Robert Chiu. Cells were labeled in methionine-free Dulbecco's modified Eagle

Table 1. Cellular dependence of standard plasmid activity

\begin{tabular}{|c|c|c|c|c|c|c|}
\hline \multirow{2}{*}{$\begin{array}{l}\text { Cell } \\
\text { line }\end{array}$} & \multicolumn{2}{|c|}{$\beta$-Actin-CAT ${ }^{a}$} & \multicolumn{2}{|c|}{ pyF101TkCAT ${ }^{\mathrm{b}}$} & \multicolumn{2}{|c|}{$\beta$-Actin-Lac $Z^{\mathrm{c}}$} \\
\hline & SD & $\bar{n}$ & SD & $n$ & SD & $n$ \\
\hline & & 5 & & 1 & & 116 \\
\hline & & 5 & - & 16 & 6738 & 22 \\
\hline & & 5 & $1.6 \pm$ & 10 & $2515 \pm 732$ & 14 \\
\hline$T$ & $16.4 \pm 8.1$ & 6 & $0.8 \pm 0.3$ & 5 & - & - \\
\hline
\end{tabular}

aThe calcium phosphate precipitate of the $\beta$-actin-CAT vector DNA was added to $60-\mathrm{mm}$ dishes initially containing $5 \times 10^{5}$ cells of the indicated cell line. Lysates were prepared $48 \mathrm{hr}$ after the addition of a total of $7 \mu \mathrm{g}$ of DNA, including $3.7 \mu \mathrm{g}$ of $\beta$ actin-CAT. Enzyme activity is represented by activity units (AU) (nanomoles of $\left[{ }^{14} \mathrm{C}\right.$ )chloramphenicol acetylated per hour at $37^{\circ} \mathrm{C}$ ) per milliliter of lysate normalized to $1 \mu \mathrm{g}$ of plasmid DNA. All values were determined within the linear range of the assay.

bActivity in transfected cells was determined as for $\beta$-actinCAT, except only $2 \mu \mathrm{g}$ of PyF101TkCAT-PA4 plasmid DNA was used. This plasmid contains a mutant polyoma enhancer linked to a truncated HSV-TK promoter and a synthetic polyadenylation signal $3^{\prime}$ of the CAT gene (Linney and Donerly 1983).

c LacZ activity is represented by AU (nanomoles of $o$-nitrophenyl- $\beta$-D-galactopyranoside cleaved per hour at $37^{\circ} \mathrm{C}$ ) per milliliter of lysate per microgram of DNA. Calcium-phosphateprecipitated DNAs were added to $9-\mathrm{cm}$ dishes initially containing $1.5 \times 10^{6}$ cells. $\beta$-Actin-LacZ DNA $(1.5 \mu \mathrm{g})$ was combined with other DNAs for a total of $20 \mu \mathrm{g} /$ plate. 
(DME) media supplemented with $400 \mu \mathrm{Ci} / \mathrm{ml}$ of $\left[{ }^{35} \mathrm{~S}\right]$ methionine and fetal bovine serum $(10 \% \mathrm{vol} / \mathrm{vol})$ for $30 \mathrm{~min}$. The same amount of lysate $\left(5 \times 10^{7}\right.$ acid insoluble $\left.\mathrm{cpm}\right)$ and antiserum $(10 \mu l)$ was used for each immunoprecipitation.

\section{Acknowledgments}

We thank Ms. Grace Cecena for expert technical assistance, Dr. Tina Trevor (Wayne State University, Detroit, MI), who constructed one of the vectors and performed preliminary experiments in this study, and Robert Chiu and Michael Karin for plasmids, 76/21-3 cells, and helpful discussion. In addition, we thank our colleagues at the La Jolla Cancer Research Foundation for their helpful criticism of the manuscript. This study was supported by grant CA42302 from the National Cancer Institute, Department of Health and Human Services and Cancer Center support grant CA30199.

\section{References}

Andrews, P.W., I. Damianov, D. Simon, G.S. Banting, C. Carlin, N.C. Dracopoli, and J. Fogh. 1984. Pluripotent embryonal carcinoma clones derived from the human teratocarcinoma cell line Tera-2. Lab. Invest. 50: 147-161.

Angel, P., M. Imagawa, R. Chiu, B. Stein, R.J. Imbra, H.J. Rahmsdorf, C. Jonat, and P. Herrlich. 1987. Phorbol ester-inducible genes contain a common cis element recognized by a TPA-modulated trans-acting factor. Cell 49: 729-739

Angel, P., K. Hattori, T. Smeal, and M. Karin. 1988. The jun proto-oncogene is positively autoregulated by its product Jun/AP-1. Cell 55: 875-885.

Ben-Ze'ev, A., G.S. Robinson, N.L.R. Bucher, and S.R. Farmer. 1988. Cell-cell and cell-matrix interactions differentially regulate the expression of hepatic and cytoskeletal genes in primary cultures of rat hepatocytes. Proc. Natl. Acad. Sci. 85: $2161-2165$.

Blessing, M., J.L. Jorcano, and W.W. Franke. 1989. Enhancer elements directing cell-type-specific expression of cytokeratin gene and changes of the epithelial cytoskeleton by transfections of hybrid cytokeratin genes, EMBO J. 8: 117-126.

Blumenberg, M. 1988. Concerted gene duplications in the two keratin gene families. J. Mol. Evol, 27: 203-211.

Borrelli, R.H.E., C. Fromental, P. Sassone-Corsi, and P. Chambon. 1986. A mutated polyoma virus enhancer which is active in undifferentiated embryonal carcinoma cells is not repressed by adenovirus-2 E1A products. Nature 321: 249-251.

Brûlet, P., C. Babinet, R. Kemler, and F. Jacob. 1980, Monoclonal antibodies against trophectoderm-specific markers during mouse blastocyst formation. Proc. Natl. Acad. Sci. 77: 4113-4117.

Burbelo, P.D., G.R. Martin, and Y. Yamada. 1988. Alphal(IV) and alpha2(IV) collagen genes are regulated by a bidirectional promoter and a shared enhancer. Proc. Natl. Acad. Sci. 85: 9679-9682.

Chisholm, J.C. and E. Houliston. 1987. Cytokeratin filament assembly in the preimplementation mouse embryo. Development 101: 565-582.

Chiu, R., W.J. Boyle, J. Meek, T. Smeal, T. Hunter, and M. Karin. 1988. The c-fos protein interacts with c-jun/AP-1 to stimulate transcription of $\mathrm{AP}-1$ responsive genes. Cell 54: $541-552$.

Curran, T., W.P. MacConnell, F. Van Straaten, and I.M. Verma. 1983. Structure of the FBJ murine osteosarcoma virus genome: Molecular cloning of its associated helper virus and the cellular homolog of the v-fos gene from mouse and human cells. Mol. Cell Biol. 3: 914-921.

Duprey, P., D. Morello, M. Vasseur, C. Babinet, H. Condamine, P. Brlet, and F. Jacob. 1985. Expression of the cytokeratin endo A gene during early mouse embryogenesis. Proc. Natl. Acad. Sci. 82: 8538-8539.

Edwards, S.A., Y.K. Rundell, and E.D. Adamson. 1988. Expression of $\mathrm{c}$-fos antisense RNA inhibits the differentiation of F9 cells to parietal endoderm. Dev. Biol. 129: 91-102.

Gorman, C. 1985. High efficiency gene transfer into mammalian cells. In DNA cloning, (ed. D.M. Glover), Vol. II, pp. 143-159. IRL Press, Oxford.

Gorman, C.M., P.W.J. Rigby, and D.P. Lane. 1985, Negative regulation of viral enhancers in undifferentiated embryonic stem cells. Cell 42: 519-526.

Gunning, P., J. Leavitt, G. Muscat, S. Ng, and L. Kedes. 1987. A human $\beta$-actin expression vector system directs high-level accumulation of antisense transcripts. Proc. Natl. Acad. Sci. 84: 4831-4835

Hai, T., F. Liu, E.A. Allegretto, M. Karin, and M.R. Green. 1988. A family of immunologically related transcription factors that includes multiple forms of ATF and AP-1. Genes Dev. 2: $1216-1226$.

Hogan, B.L.M., D.P. Barlow, and R. Tilly. 1983. F9 teratocarcinoma cells as a model for the differentiation of parietal and visceral endoderm in the mouse embryo. Cancer Surv. 2: $115-140$.

Ichinose, Y., T. Morita, F. Zhang, S. Srimahasongcram, M.L.C Tondella, M. Matsumoto, M. Nozaki, and A. Matsushiro, 1988. Nucleotide sequence and structure of the mouse cytokeratin endoB gene. Gene 70: 85-95.

Jackson, B.W., C. Grund, E. Schmid, K. Burke, W. Franke, and K. Illmensee. 1980. Formation of cytoskeletal elements during mouse embryogenesis. Intermediate filaments of the cytokeratin type and desmosomes in preimplantation embryos. Differentiation 17; 161-179.

Karpinski, B., L. Yang, P. Cacheris, G.D. Morle, and J.M. Leiden. 1989. The first intron of the 4F2 heavy-chain gene contains a transcriptional enhancer element that binds multiple nuclear proteins. Mol. Cell Biol. 9: 2588-2597.

Kawamoto, T., K. Makino, H. Niwa, H. Sugiyama, S. Kimura, M. Amemura, A. Nakata, and T. Kakunaga. 1988. Identification of the human $\beta$-actin enhancer and its binding factor. Mol. Cell Biol. 8: 267-272.

Kulesh, D.A. and R.G. Oshima. 1988. Cloning of the human keratin 18 gene and its expression in non-epithelial mouse cells. Mol. Cell Biol. 8: 1540-1550.

. 1989. Complete structure of the gene for human keratin 18. Genomics 4: 339-347.

Lee, W., P. Mitchell, and R. Tjian. 1987. Purified transcriptional factor AP-1 interacts with TPA-inducible enhancer elements. Cell 49: 741-752.

Lenardo, M.J., L. Staudt, P. Robbins, A. Kuang, R.C. Mulligan, and D. Baltimore. 1989. Repression of the IgH enhancer in teratocarcinoma cells associated with a novel octamer factor. Science 243: 544-546.

Linney, E. and S. Donerly. 1983. DNA fragments from F9 PyEC mutants increase expression of heterologous genes in transfected F9 cells. Cell 35: 693-699.

Lockett, T.J. and M.J. Sleigh. 1987. Oncogene expression in differentiating F9 mouse embryonal carcinoma cells. Exp. Cell Res. 173: 370-378.

Mason, I., D. Murphy, and B. Hogan. 1985. Expression of c-fos in parietal endoderm, amnion and differentiating F9 teratocarcinoma cells. Differentiation 30: 76-81.

Miller, A.D., T. Curran, and I.M. Verma. 1984. c-fos protein can 
induce cellular transformation: A novel mechanism of activation of cellular oncogene. Cell 36: 51-60.

Moll, R., W.W. Franke, D.L. Schiller, B. Geiger, and R. Krepler. 1982. The catalog of human cytokeratins: Patterns of expression in normal epithelia tumors and cultured cells. Cell 31: 11-24.

Muller, R. and E.F. Wagner. 1984. Differentiation of F9 teratocarcinoma stem cells after transfer of c-fos proto-oncogenes. Nature 311: 438-442.

Nakabeppu, Y., K. Ryder, and D. Nathans. 1988. DNA binding activities of three murine iun proteins: Stimulation by fos. Cell 55: 907-915.

Onclercq, R., A. Lavenu, and C. Cremisi. 1989. Pleiotropic derepression of developmentally regulated cellular and viral genes by c-myc proto-oncogene products in undifferentiated embryonal carcinoma cells. Nucleic Acids Res. 17: 736753.

Oshima, R.G. 1981. Identification and immunoprecipitation of cytoskeletal proteins from murine extra-embryonic endodermal cells. J. Biol. Chem. 256: 8124-8133.

- 1982. Developmental expression of murine extra-embryonic endodermal cytoskeletal proteins. $J$. Biol. Chem. 257: 3414-3421.

Oshima, R.G., W.E. Howe, F.G. Klier, E.D. Adamson, and L.H. Shevinsky. 1983. Intermediate filament protein synthesis in preimplantation murine embryos. Dev. Biol. 99: 447-455.

Oshima, R.G., K. Trevor, L.H. Shevinsky, O.A. Ryder, and G. Ceceña. 1988. Identification of the gene coding for the Endo B murine cytokeratin and its methylated, stable inactive state in mouse nonepithelial cells. Genes Dev. 2: 505-516.

Rauscher, F.J., D.R. Cohen, T. Curran, T.J. Bos, P.K. Vogt, D. Bohmann, R. Tjian, and B.R. Franza, Jr. 1988. Fos-associated protein p39 is the product of the jun-proto-oncogene. Science 240: 1010-1016.

Rossi, P. and B. de Crombrugghe. 1987. Identification of a cellspecific transcriptional enhancer in the first intron of the mouse alpha 2 (type I) collagen gene. Proc. Natl. Acad. Sci. 84: $5590-5594$.

Ruther, U., E.F. Wagner, and R. Muller. 1985. Analysis of the differentiation-promoting potential of inducible c-fos gene introduced into embryonal carcinoma cells. EMBO $J$. 4: $1775-1781$.

Saiki, R.K., D.H. Gelfand, S. Stoffel, S.J. Scharf, R. Higuchi, G.T. Horn, K.B. Mullis, and H.A. Erlich. 1988. Primer-directed enzymatic amplification of DNA with a thermostable DNA polymerase. Science 239: 487-491.

Sassone-Corsi, P., J.C. Sisson, and I.M. Verma. 1988a. Transcriptional autoregulation of the proto-oncogene fos. Nature 334: 314-319.

Sassone-Corsi, P., W.W. Lamph, M. Kamps, and I.M. Verma. $1988 \mathrm{~b}$. fos-associated cellular p39 is related to nuclear transcription factor AP-1. Cell 54: 553-560.

Sassone-Corsi, P., L.J. Ransone, W.W. Lamph, and I.M. Verma. 1988c. Direct interaction between fos and jun nuclear oncoproteins: Role of the "leucine zipper" domain. Nature 336: 692-695.

Silver, L.M., G.R. Martin, and S. Strickland. 1983. Teratocarcinoma stem cells. Cold Spring Harbor Conf. Cell Proliferation 10:

Speck, N.A. and D. Baltimore. 1987. Six distinct nuclear factors interact with the 75-base-pair repeat of the Moloney murine leukemia virus enhancer. Mol. Cell Biol. 7: 1101-1110.

Steinert, P.M. and D.A.D. Parry. 1985. Intermediate filaments: Conformity and diversity of expression and structure. Annu. Rev. Cell. Biol. 1: 41-65.

Tabor, J.M. and R.G. Oshima. 1982. Identification of mRNA species that code for extra-embryonic endodermal cytoskeletal proteins in differentiated derivatives of murine embryonal carcinoma cells. I. Biol. Chem. 257: 8771-8774.

Trevor, K. and R.G. Oshima. 1985. Preimplantation mouse embryos and liver express the same type I keratin gene product. J. Biol. Chem. 260: 15885-15891.

Young, K.S., R. Weigel, S. Hiebert, and J.R. Nevins. 1989. Adenovirus ElA-mediated negative control of genes activated during F9 differentiation. Mol. Cell Biol. 9: 3109-3113.

Zerial, M., L. Toschi, R. Ryseck, M. Schuermann, R. Müller, and R. Bravo. 1989. The product of a novel growth factor activated gene, fos $B$, interacts with Jun proteins enhancing their DNA binding activity. EMBO I. 8: 805-813. 


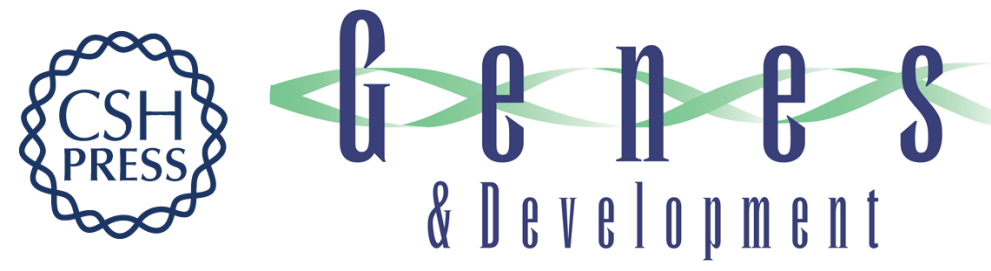

\section{Activation of an intron enhancer within the keratin 18 gene by expression of c-fos and c-jun in undifferentiated F9 embryonal carcinoma cells.}

R G Oshima, L Abrams and D Kulesh

Genes Dev. 1990, 4:

Access the most recent version at doi:10.1101/gad.4.5.835

References This article cites 51 articles, 21 of which can be accessed free at: http://genesdev.cshlp.org/content/4/5/835.full.html\#ref-list-1

License

Email Alerting Service

Receive free email alerts when new articles cite this article - sign up in the box at the top right corner of the article or click here.

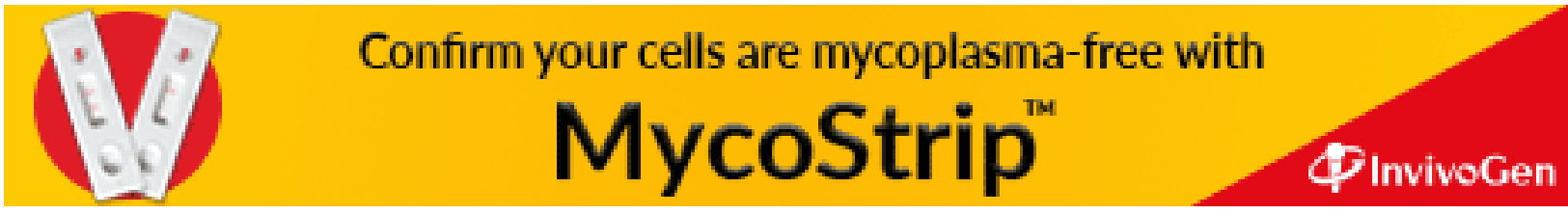

